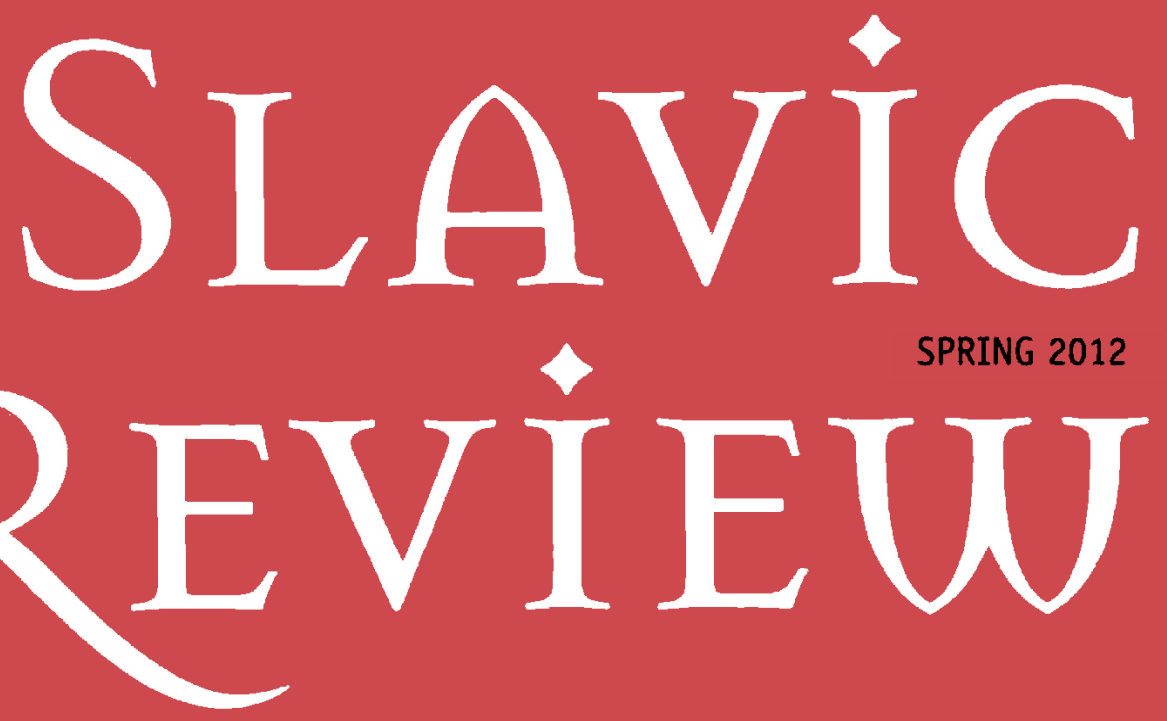

Interdisciplinary Quarterly of Russian, Eurasian, and East European Studies

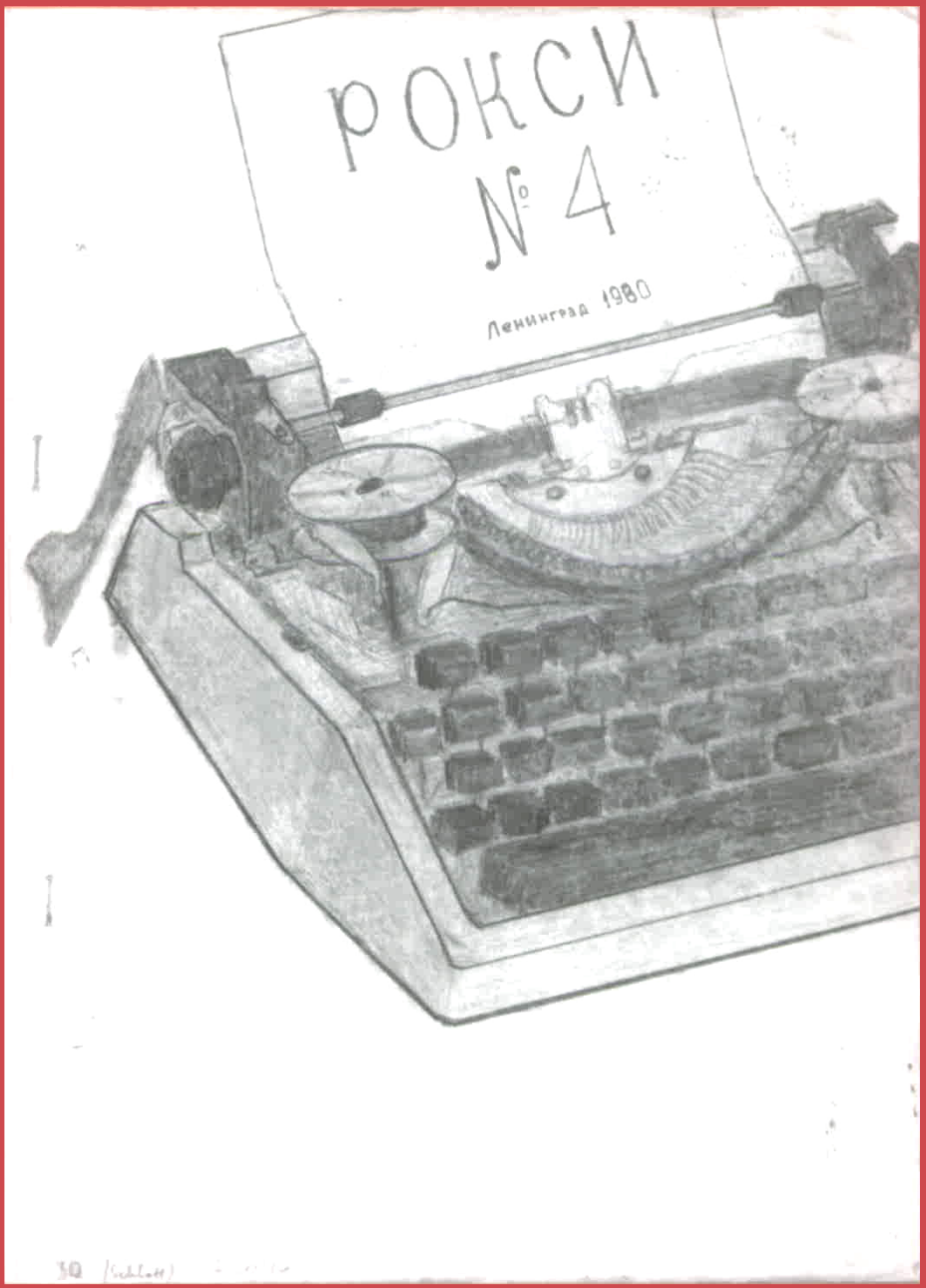




\title{
EDITOR
}

MARK D. STEINBERG

Managing Editor, Jane T. Hedges

EDITORIAL ASSISTANTS

\section{PompILIA BurCică}

ANya Hamrick-Nevinglovskaya

ELANA JaKel

\section{EDITORIAL BOARD}

\begin{abstract}
History
John Connelly, University of California, Berkeley - Yaroslav Hrytsak, L'viv National University and Central European University, Budapest $\bullet$ Adeeb Khalid, Carleton College - William Rosenberg, University of Michigan - Maria Todorova, University of Illinois • Stefan Troebst, University of Leipzig $\bullet$ Lynne Viola, University of Toronto $\bullet$ Mark von Hagen, Arizona State University • Sergei Zhuravlev, Institute of Russian History of the Russian Academy of Sciences, Moscow
\end{abstract}

Literature, Film, and the Arts

Clare Cavanagh, Northwestern University $\bullet$ Gregory Freidin, Stanford University • Catriona Kelly, Oxford University • Christina Kiaer, Northwestern University • Judith Kornblatt, University of Wisconsin, Madison - Michał Paweł Markowski, University of Illinois, Chicago and Jagellonian University, Kraków • Eric Naiman, University of California, Berkeley • Catharine Nepomnyashchy, Columbia University • Andrei Zorin, Oxford University

\section{Social Sciences}

Judit Bodnár, Central European University, Budapest • M. Steven Fish, University of California, Berkeley • Susan Gal, University of Chicago • Elena Gapova, European Humanities Universily, Vilnius-Minsk and Western Michigan University • Grigorii Golosov, European University, St. Petersburg • Bruce Grant, New York University • Jan Kubik, Rutgers University - Pauline Jones Luong, Brown University • Blair Ruble, Kennan Institute

Cover image: Cover of the Samizdat journal ROKSI, no. 4 (1980). Archiv der Forschungsstelle Osteuropa an der Universität Bremen, accessible at www.forschungsstelle.uni-bremen.de. Used with permission of the archive.

The editors assume no responsibility for statements of fact or opinion made by contributors.

Slavic Review (formerly The American Slavic and East European Review) is published quarterly by the Association for Slavic, East European, and Eurasian Studies, Inc. (ASEEES, formerly the American Association for the Advancement of Slavic Studies, AAASS) and is sent to all association members. Members also receive NewsNet, the ASEEES newsletter. Membership is open to individuals interested in Slavic studies and the study of the non-Slavic peoples of eastern Europe and Eurasia.

Membership Dues: students $-\$ 35.00$; those with salaries under $\$ 30,000-\$ 55.00 ; \$ 30,000-$ $\$ 39,999-\$ 70.00 ; \$ 40,000-\$ 49,999-\$ 85.00 ; \$ 50,000-\$ 59,999-\$ 115.00 ; \$ 60,000-\$ 74,999-$ $\$ 135.00 ; \$ 75,000-\$ 99,999-\$ 155.00 ; \$ 100,000-\$ 124,999-\$ 180.00 ; \$ 125,000$ and over$\$ 200.00$. Joint members with one subscription to Slavic Review, add $\$ 40.00$ to dues of higher paid member. For members living in Canada or Mexico, please add $\$ 25.00$ for shipping; for members living overseas, please add $\$ 35.00$. Subscriptions without membership are: for Electronic-Only, $\$ 200$; for Electronic+Print, $\$ 240.00$ within the United States and $\$ 275.00$ outside the United States. Single current and back issues to subscribers are $\$ 50.00$; for ASEEES members, $\$ 25.00$ each, plus shipping. Correspondence regarding Slavic Review subscriptions should be sent to JSTOR at: participation@jstor.org; Web site: www.jstor.org. Correspondence regarding membership, news items for NerusNet, or changes of address should be sent to ASEEES, 203C Bellefield Hall, 315 S. Bellefield Ave., Pittsburgh, PA 15260-6424. Telephone: (412) 648-9911; fax: (412) 648-9815; e-mail: aseees@pitt.edu; Web site: www.aseees.org.

Published by the Association for Slavic, East European, and Eurasian Studies, Inc. Cover design by B. Williams \& Associates, Durham, North Carolina; the typeface Mason is from Emigre Fonts. Text set in Baskerville by Newgen-Austin, Austin, Texas. Printed by Cadmus Professional Communications, Lancaster, Pennsylvania. Periodicals postage paid at Pittsburgh, Pennsylvania, and 


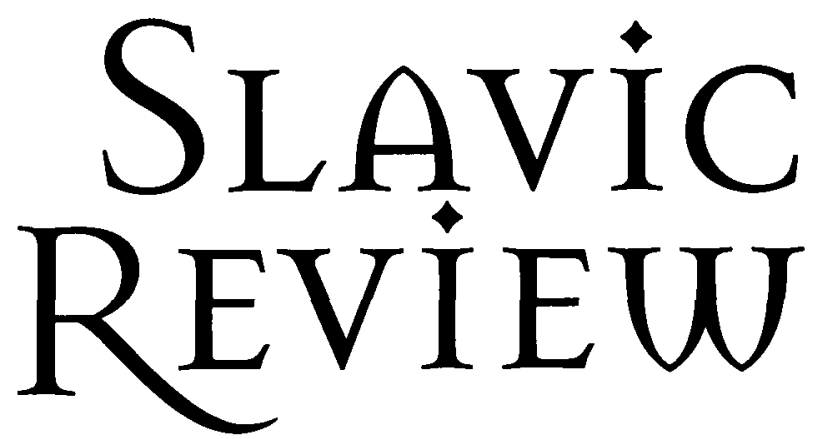

INTERDISCIPLINARY QUARTERLY OF RUSSIAN, EURASIAN, AND EAST EUROPEAN STUDIES

VOLUME 71 NUMBER 1 • SPRING 2012

CONTRIBUTORS

vi

ABSTRACTS

viii

ARTICLES

Empire by Consent: Strakhov, Dostoevskii, and the Polish Uprising of 1863

EDYTA M. BOJANOWSKA

Holidays in Kazan: The Public Sphere and the Politics

of Religious Authority among Tatars in 1914

NORIHIRO NAGANAWA

Sergei Eisenstein's Ivan the Terrible and the Renaissance:

An Example of Stalinist Cosmopolitanism?

KATERINA CLARK

Samizdat and Soviet Dissident Publics

ANN KOMAROMI

The Russian-Speaking Jewish Diaspora in Translation:

Liudmila Ulitskaia's Daniel Stein, Translator

MARGARITA LEVANTOVSKAYA

Black Work, Green Money: Remittances, Ritual, and Domestic Economies in Southern Kyrgyzstan MADELEINE REEVES

\section{FEATURED REVIEWS}

Gerald W. Creed, Masquerade and Postsocialism: Ritual and Cultural Dispossession in Bulgaria (Katherine Verdery and Jane Sugarman) 
Bożena Shallcross, The Holocaust Object in Polish and

Polish-Jewish Culture (Rachel Feldhay Brenner)

Barbara Alpern Engel. Breaking the Ties That Bound:

The Politics of Marital Strife in Late Imperial

Russia (David L. Ransel)

Michael A. Reynolds, Shattering Empires: The Clash

and Collapse of the Ottoman and Russian Empires, 1908-1918 (Mark L. von Hagen)

\section{FILM REVIEWS}

Sergei Loznitsa, dir., Revue (Polly Jones) 147

Joanna Grudzińska, dir., K.O.R. (Shana Penn) 148

\section{BOOK REVIEWS}

Jörn Happel and Christophe von Werdt, eds., with assistance from Mira Jovanović, Osteuropa kartiert-Mapping Eastern Europe (Steven Seegel)

David L. Cooper, Creating the Nation: Identity and Aesthetics in Early Nineteenth-Century Russia and Bohemia (Andrei Zorin)

Jane Costlow and Amy Nelson, eds., Other Animals: Beyond the Human in Russian Culture and History (Douglas Weiner)

Karoly Attila Soos, Politics and Policies in Post-Communist Transition: Primary and Secondary Privatisation in Central Europe and the Former Soviet Union (Demetrius S. Iatridis)

Bruce R. Berglund and Brian Porter-Szũcs, eds., Christianity and Modernity in Eastern Europe (Konrad Sadkowski)

Felix Ackermann, Palimpsest Grodno: Nationalisierung, Nivellierung und Sowjetisierung einer mitteleuropäischen Stadt 1919-1991 (Christoph Mick)

Jacek Andrzej Młynarczyk and Jochen Böhler, eds. Der Judenmord in den eingegliederten polnischen Gebieten 1939-1945 (Catherine Epstein)

Svetla Baloutzova, Demography and Nation: Social Legislation and Population Policy in Bulgaria, 1918-1944 (Mary Neuburger)

Mark Biondich, The Balkans: Revolution, War, and Political Violence since 1878 (Richard C. Hall)

Andrea Despot, Amerikas Weg auf den Balkan: Zur Genese der Beziehungen zwischen den USA und Südosteuropa, 1820-1920 (John K. Cox) 
Ulf Brunnbauer, ed., Transnational Societies, Transterritorial

Politics: Migrations in the (Post-) Yugoslav Region 19th-21st

Century (Nick Miller)

Klaus Buchenau, Auf russischen Spuren: Orthodoxe Antiwestler in Serbien, 1850-1945 (Radmila Radić)

Hannes Grandits and Karin Taylor, eds., Yugoslavia's Sunny Side: A History of Tourism in Socialism (1950s-1980s) (Paulina Bren)

Liubka Lipcheva-Prandzheva, Bitie v prevoda: Bălgarska literatura na nemski ezik (XIX-XX v.). (Rumjana Ivanova-Kiefer)

Peter Hames, Czech and Slovak Cinema: Theme and Tradition (David Sorfa)

Maria Golubeva and Robert Gould, eds. Shrinking Citizenship: Discursive Practices That Limit Democratic Participation in Latvian Politics (Daina S. Eglitis)

Kateryna Pishchikova, Promoting Democracy in Postcommunist Ukraine: The Contradictory Outcomes of US Aid to Women's NGOs (Sarah D. Phillips)

Volodymyr Kulyk, Dyskurs ukraiins'kykh medii: Identychnosti, ideolohii, vladni stosunky (Marta Dyczok)

András Kovács, The Stranger at Hand: Antisemitic Prejudices in Post-Communist Hungary (Gábor T. Rittersporn)

Christopher Cuiić and Peter Sanfey, In Search of the Balkan Recovery: The Political and Economic Reemergence of South-Eastern Europe (John Marangos)

Vassilis Nitsiakos, On the Border: Transborder Mobility, Ethnic Groups and Boundaries on the Albanian-Greek Frontier (Anastasia Karakasidou)

Paul Dukes, Graeme P. Herd, and Jarmo Kotilaine, Stuarts and Romanovs: The Rise and Fall of a Special Relationship (Brian Davies)

Iu. P. Anshakov, A. E. Zagrebin, S. V. Liubichankovskii, eds., Mestnoe upravlenie v poreformennoi Rossii: Mekhanizmy vlasti $i$ ikh effektivnost': Svodnye materialy zaochnoi diskussii (Peter Weisensel)

Francis W. Wcislo, Tales of Imperial Russia: The Life and Times of Sergei Witte, 1849-1915 (Cynthia Hyla Whittaker)

Jörn Happel, Nomadische Lebenswelten und zarische Politik: Der Aufstand in Zentralasien 1916 (Shoshana Keller)

Gudrun Persson, Learning from Foreign Wars: Russian Military Thinking, 1859-73 (Jamie Cockfield) 
Yohanan Petrovsky-Shtern, Jews in the Russian Army, 1827-1917: Drafted into Modernity (Daniel Orlovsky)

Scott M. Kenworthy, The Heart of Russia: Trinity-Sergius, Monasticism, and Society after 1825 (Robert H. Greene)

Irina Paert, Spiritual Elders: Charisma and Tradition in Russian Orthodoxy (Heather J. Coleman)

183

Dany Savelli, ed., La Religion de l'Autre: Réactions et interactions entre religions dans le monde russe (Agnès Kefeli)

184

Anna Lisa Crone, Eros and Creativity in Russian Religious Renewal: The Philosophers and the Freudians (Frances Nethercott)

Asif A. Siddiqi, The Red Rockets' Glare: Spaceflight and the Soviet Imagination, 1857-1957 (Amy Nelson)

Paul R. Josephson, Lenin's Laureate: Zhores Alferov's Life in Communist Science (Harley Balzer)

John A. Martens, Secret Patenting in the USSR and Russia (Malcolm R. Hill)

Igal Halfin, Red Autobiographies: Initiating the Bolshevik Self (Thomas Seifrid)

Eva Maurer, Wege zum Pik Stalin: Sowjetische Alpinisten, 1928-1953 (Manfred Zeller)

Donald Filtzer, The Hazards of Urban Life in Late Stalinist Russia: Health, Hygiene, and Living Standards, 1943-1953 (Kenneth M. Pinnow)

Alexandre Sumpf, Bolcheviks en campagne: Paysans et éducation politique dans la Russie des années 1920 (James D. White)

E. Thomas Ewing, Separate Schools: Gender, Policy, and Practice in Postwar Soviet Education (Karen Petrone)

Jeremy Smith and Melanie Ilic, eds., Khrushchev in the Kremlin: Policy and Government in the Soviet Union, 1953-1964 (Martin McCauley)

A. Ross Johnson, Radio Free Europe and Radio Liberty: The CIA Years and Beyond (Sheldon Anderson)

Blaine R. Chiasson, Administering the Colonizer: Manchuria's Russians under Chinese Rule, 1918-29 (David Wolff)

Predrag Cicovacki and Maria Granik, eds., Dostoevsky's Brothers Karamazov: Art, Creativity, and Spirituality (Nina Perlina)

Musya Glants, Where Is My Home? The Art and Life of the Russian Jewish Sculptor Mark Antokolsky, 1843-1902 (Mirjam Rajner) 
Gabriella Safran, Wandering Soul: The Dybbuk's Creator, S. An-sky (Barry Trachtenberg)

Mikhail Krutikov, From Kabbalah to Class Struggle: Expressionism, Marxism, and Yiddish Literature in the Life and Work of Meir Wiener (Anna Shternshis)

D. I. Chizhevskii, Izbrannoe v trekh tomakh. Vol. 1, Materialy $k$ biografii (1894-1977), ed. V. Iantsen (Judith Deutsch Kornblatt)

Catherine Depretto, Le Formalisme en Russie, foreword, Michel Aucouturier (Laura Beraha)

Pauline Fairclough, ed., Shostakovich Studies 2 (Neil Minturn)

Irina Papkova, The Orthodox Church and Russian Politics (John Garrard)

Jarrett Zigon, "HIV Is God's Blessing": Rehabilitating Morality in Neoliberal Russia (Erin Koch)

Lilia Shevtsova, Lonely Power: Why Russia Has Failed to Become the West and the West Is Weary of Russia, trans. Antonina W. Bouis (Kathryn Stoner-Weiss) 